\title{
Role of the colicin A lysis protein in the expression of the colicin A operon
}

\author{
Danièle Cavard \\ Tel: +33491164485. Fax: +33491712124. \\ e-mail : cavard@ibsm.cnrs-mrs.fr
}

Laboratoire d'Ingénierie des Systèmes

Macromoléculaires, CNRS, 31 chemin Joseph Aiguier, BP 71, 13402 Marseille Cedex 20, France

\begin{abstract}
The involvement of the cal gene, which encodes the colicin A lysis protein, in the expression of the colicin A operon is demonstrated. Colicin A synthesis by Escherichia coli was studied at various temperatures in cells containing either the wild-type colicin A operon or the colicin A operon with the cal gene deleted. The amount of colicin A produced was lower in cells containing the colicin A operon devoid of the cal gene than in wild-type cells. In cells treated with the antibiotic globomycin, the synthesis of colicin A was blocked in null cal mutants at all temperatures. It was blocked only at low temperature in cells containing the wild-type colicin A operon, but not in cells subjected to heat shock or azide treatment. The cal gene product may be an activator of colicin A expression and of its own expression. An unidentified product, possibly a heat-shock protein, may also be involved and could complement the cal gene product in some situations.
\end{abstract}

Keywords: Escherichia coli, colicin, colicin lysis protein, globomycin, heat-shock protein

\section{INTRODUCTION}

The colicin A lysis protein (Cal) is a lipopeptide synthesized by cells of Escherichia coli carrying the plasmid pColA. Its stuctural gene, cal, is in the colicin A operon downstream from the colicin A structural gene, $c a a$, both genes being under the control of an SOS promoter (Lloubès et al., 1986). The two genes are expressed together after addition of mutagenic agents, but their products are addressed differently. Colicin A is a globular protein which accumulates in the cytoplasm before being exported into the medium with the help of $\mathrm{Cal}$ by an unknown mechanism. Cal is synthesized as a precursor that matures by acylation and processing in the inner membrane like all other lipoproteins (Braun \& Wu, 1994).

The regulation of colicin operons is complex. They are under the control of SOS regulation, catabolite repression, stringent response, anaerobiosis (Pugsley, 1984; Eraso \& Weinstock, 1992; Ferrer et al., 1996) and growth phase (Eraso et al., 1996). The expression of the colicin A operon is significantly delayed at low temperature. However, a heat shock restores normal synthesis, except in an $r p o H$ mutant deficient in the RNA polymerase sigma factor $\sigma^{32}$, suggesting that one or more heat-shock proteins play a role in the expression of the colicin A operon (Cavard, 1995). Similar results have been obtained for an operon containing only the cal gene, indicating that the synthesis of $\mathrm{Cal}$ is slowed down at low temperature. The insertion into the inner membrane of the precursor of $\mathrm{Cal}$ and its subsequent acylation and processing might be temperature-dependent like those of Braun's lipoprotein (Tian et al., 1989). Consequently, the unmodified precursor form of $\mathrm{Cal}$, $\mathrm{pCal}$, may be involved in the delay of colicin A expression at low temperature (Cavard, 1995).

To investigate this possibility, in the study described here, cells induced for colicin A synthesis were treated with globomycin, a specific inhibitor of LspA, the lipoprotein signal peptidase that cleaves the acylated precursor form of lipoproteins into apolipoprotein and signal peptide (Inukai et al., 1978; Hussain et al., 1980). Globomycin provokes accumulation of the modified precursor form of $\mathrm{Cal}, \mathrm{pCal}^{\mathrm{m}}$, and does not alter colicin A synthesis in cells induced at either 37 or $42^{\circ} \mathrm{C}$ (Cavard et al., 1989; Cavard, 1992). In induced cells grown at $30^{\circ} \mathrm{C}$ in rich medium, globomycin significantly reduced the expression of the colicin A operon. In cells devoid of the cal gene, it blocked expression of the colicin A at all temperatures. This is the first time that such a phenotype caused by a null mutation of a gene encoding a colicin lysis protein has been described. The cal gene product 
may be an activator of the expression of the colicin A operon, and an uncharacterized member of the heat shock regulon may also be involved.

\section{METHODS}

Bacterial strains and plasmids. Escherichia coli K12 W3110 $\left(\mathrm{Nal}^{\mathrm{R}}\right)$, E. coli W3110 degP41 and E. coli 1320 rpoH16 zhf50::Tn10 are from the author's laboratory collection (Cavard et al., 1989, Cavard, 1995). The plasmid pColA9 contains the wild-type colicin A operon (Lloubès et al., 1986). Plasmids pJMM1 and pColA9F1 contain the colicin A operon from which the cal gene has been deleted. pJMM1 is pColA with a Tn1 transposon located in the intergenic area between the caa and the cal genes; pColA9F1 is pColA9 from which a StuI-EcoRV fragment encoding the cai (colicin $A$ immunity) and the cal genes has been deleted (Geli et al., 1986). Plasmids containing a mutation within the cal gene have been constructed from pColA9 (Howard et al., 1989). They include plasmids containing a single base substitution leading to an amino acid substitution in the mature form of Cal: pA2 (R7E), pG4 (G11E), pV1 (V14R); and plasmids with a stop codon in the cal gene: pS16 and pS18, which encode a truncated Cal containing the first 16 and the first $18 \mathrm{~N}$-terminal amino acids, respectively.

Growth conditions. Strains were grown at $30^{\circ} \mathrm{C}$ with shaking in LB medium or in $\mathrm{M} 9$ medium supplemented with thiamin $\left(1 \mu \mathrm{g} \mathrm{ml}^{-1}\right)$, lactate $(0.4 \%, \mathrm{v} / \mathrm{v})$ and Casamino acids $(0.01 \%$, $\mathrm{w} / \mathrm{v})$. The $\mathrm{OD}_{600}$ of the cultures was adjusted to 1 before induction with $300 \mathrm{ng}$ mitomycin $\mathrm{C} \mathrm{ml}^{-1}$. At time zero of induction, the cultures were incubated at $30^{\circ} \mathrm{C}, 37^{\circ} \mathrm{C}$ or $42{ }^{\circ} \mathrm{C}$. Globomycin, a gift of Dr M. Inukai (Sankyo Company, Tokyo, Japan), was either dissolved in methanol $\left(10 \mathrm{mg} \mathrm{ml}^{-1}\right)$ or in dimethylsulfoxide $\left(5 \mathrm{mg} \mathrm{ml}^{-1}\right)$, and added to a final concentration of $100 \mu \mathrm{g} \mathrm{ml}^{-1}$ after $15-20 \mathrm{~min}$ induction. Sodium azide (either 2 or $3 \mathrm{mM}$ as indicated), potassium cyanide $(2 \mathrm{mM})$ and EDTA $(3 \mathrm{mM})$ were added at time zero of induction.

Electrophoresis and immunoblotting. Routinely, $15 \mu \mathrm{l}$ of culture was taken after $3 \mathrm{~h}$ induction at $42{ }^{\circ} \mathrm{C}, 3.5 \mathrm{~h}$ at $37^{\circ} \mathrm{C}$ and $4 \mathrm{~h}$ at $30^{\circ} \mathrm{C}$, mixed with $10 \mu \mathrm{l}$ of loading buffer, heated to $96^{\circ} \mathrm{C}$ and loaded either on an $11 \%$ polyacrylamide-SDS gel for colicin A identification or on an $8-16 \%$ polyacrylamideurea-SDS gel for Cal identification. Proteins in unstained gels were transferred onto a nitrocellulose filter $(200 \mathrm{~nm}$ pore size; Scheicher \& Schuell). To detect colicin A, the blots were incubated with either polyclonal or monoclonal antibodies. Serum from a rabbit inoculated with a hybrid protein, called NS protein, containing the $\mathrm{N}$-terminal part of colicin $\mathrm{A}$ fused to the sequence of the mature Cal except for the first $\mathrm{N}$ terminal cysteine residue (Howard \& Lindsay, 1992) was used to detect Cal.

Radioactive labelling. Cells were grown in M9 medium and induced with mitomycin C. After $70 \mathrm{~min}$ induction at $37^{\circ} \mathrm{C}$ or $130 \mathrm{~min}$ at $30^{\circ} \mathrm{C},\left[{ }^{35} \mathrm{~S}\right]$ Protein Labeling Mix from NEN $\left(1175 \mathrm{Ci} \mathrm{mmol}^{-1}\right)$ was added at $20 \mu \mathrm{Ci} \mathrm{m}^{-1}(1 \mu \mathrm{Ci}=37 \mathrm{kBq})$ and chased $1 \mathrm{~min}$ later with a mix of unlabelled methionine and cysteine $\left(500 \mu \mathrm{g} \mathrm{ml}^{-1}\right)$. At various times thereafter, samples of the cultures were taken and immunoprecipitated with polyclonal antibodies against colicin $\mathrm{A}$ as described previously (Cavard, 1992).

\section{RESULTS}

\section{The cal gene is required for colicin A synthesis in the presence of globomycin}

The two gene products of the colicin A operon (colicin $\mathrm{A}$ and $\mathrm{Cal}$ ) are synthesized immediately after induction by a mutagenic agent, except at $30^{\circ} \mathrm{C}-$ at this temperature synthesis is delayed. To test the involvement of the precursor form of $\mathrm{Cal}$ in this delay, induced cells were treated with globomycin. Cells grown in rich medium at $30^{\circ} \mathrm{C}$ were induced with mitomycin $\mathrm{C}$, a mutagenic agent, and incubated at various temperatures in the presence or absence of globomycin. After induction, samples were analysed by SDS-PAGE (Fig. 1a). In W3110(pColA9) cells (containing the wild-type colicin A operon), large amounts of colicin A were produced at $37^{\circ} \mathrm{C}$ and $42^{\circ} \mathrm{C}$ in the presence or absence of globomycin. At $30^{\circ} \mathrm{C}$, colicin $\mathrm{A}$ accumulated in untreated cells, but not in the presence of globomycin.

The experiment was repeated with W3110 carrying either pColA9F1 (Fig. 1a) or pJMM1 (not shown), which both contain the colicin A operon with the cal gene deleted. In the absence of globomycin, colicin A production was somewhat reduced at all temperatures compared to that of cells carrying pColA9. But, strikingly, in the presence of globomycin, colicin A synthesis was inhibited at all temperatures. Thus the presence of the $c a l$ gene may be required for normal production of colicin A, but, more importantly, is essential for colicin A synthesis in the presence of globomycin.

Various cal mutants from the laboratory collection were tested for production of colicin A. Colicin A production was similar to that in the wild-type in mutants with point mutations in the region of the cal gene encoding the mature form of $\mathrm{Cal}$ and in mutants with deletions of the C-terminal end of Cal. The synthesis of colicin A in induced W3110 cells carrying plasmid pA2 (R7E), or pV1 (V14R), or pS18 (which encodes a truncated Cal containing the first $18 \mathrm{~N}$-terminal amino acids) (Fig. 1a), or pG4 (G11E), or pS16 (which encodes a truncated Cal containing the first $16 \mathrm{~N}$-terminal amino acids) (not shown) was similar to that in cells carrying pColA9 although these plasmids encode inactive Cals. Thus the mature form of $\mathrm{Cal}$ seemed not to be responsible for the phenotype of null cal mutants described above, suggesting that the sequence signal of Cal might be involved.

The amount of colicin A produced was analysed by Western blotting using monoclonal antibodies against colicin A (Fig. 1b). This detection method provided evidence for colicin A production in all cells. In W3110(pColA9), high amounts of colicin A were detected in both the presence and absence of globomycin at 37 and $42{ }^{\circ} \mathrm{C}$, whereas only small amounts were produced at $30^{\circ} \mathrm{C}$ in the presence of globomycin. In W3110(pJMM1), the amounts of colicin A were significantly higher in the absence than in the presence of globomycin at each temperature, but were much reduced compared with W3110(pColA9). No colicin A fragments 
(a)

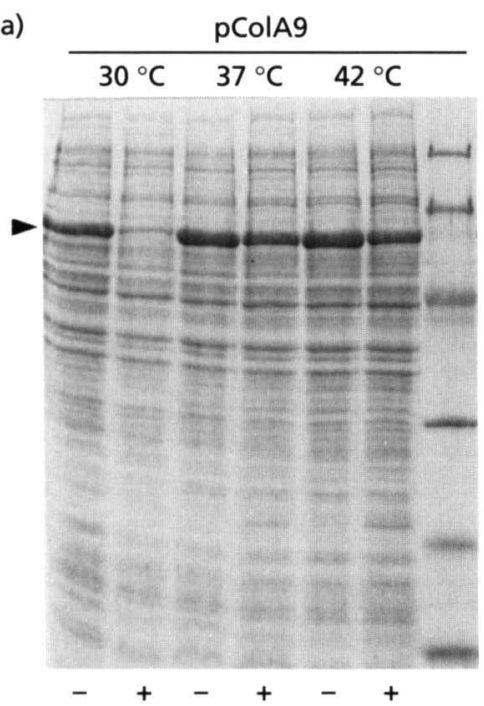

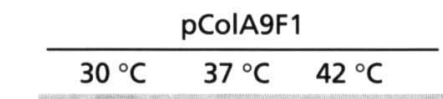
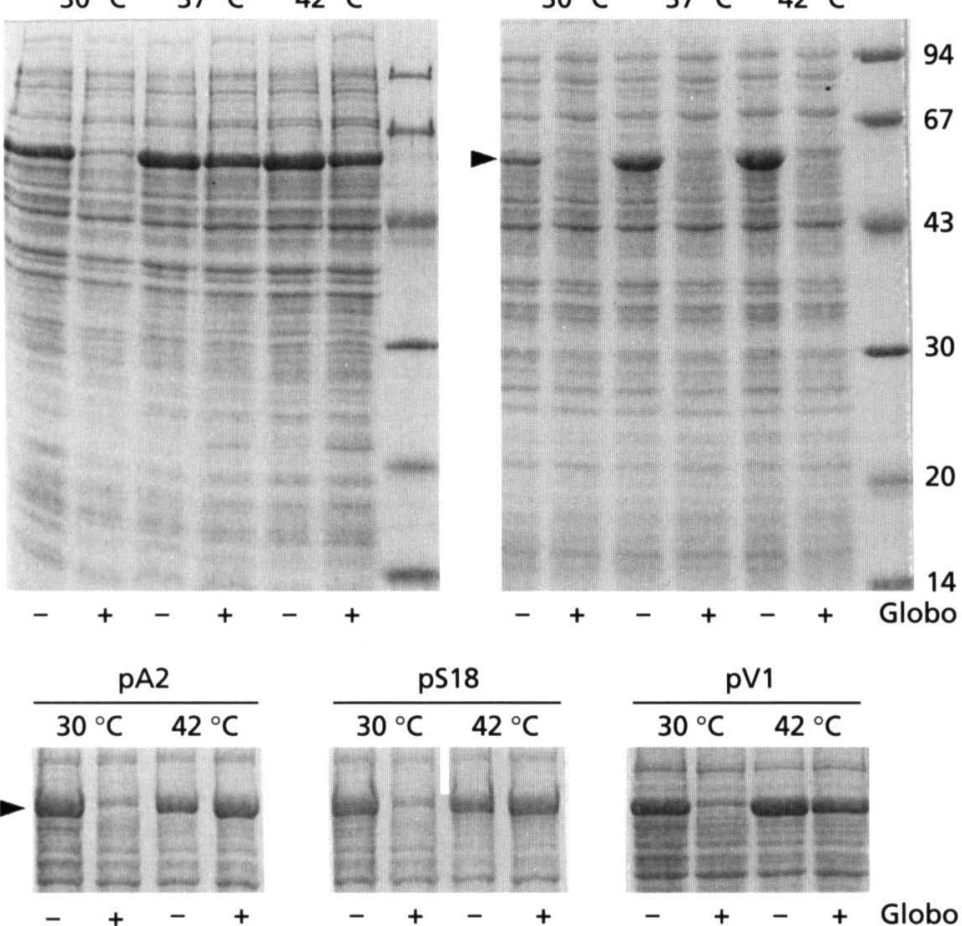
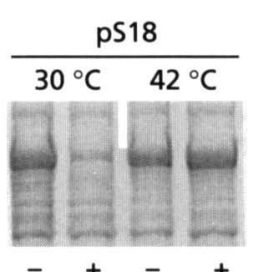

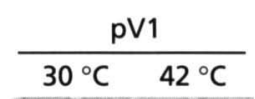

Goboo

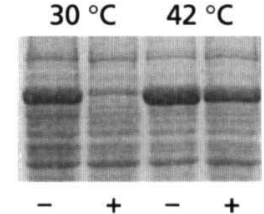

(b)

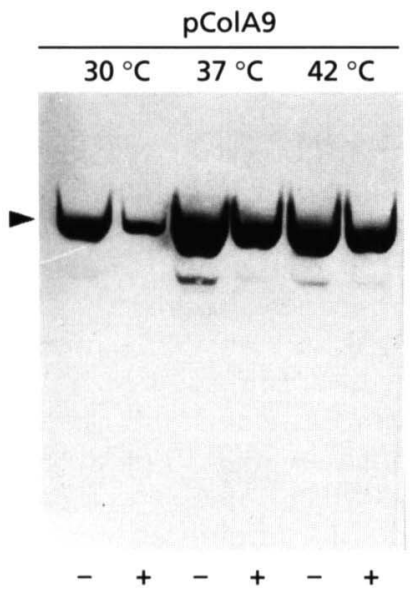

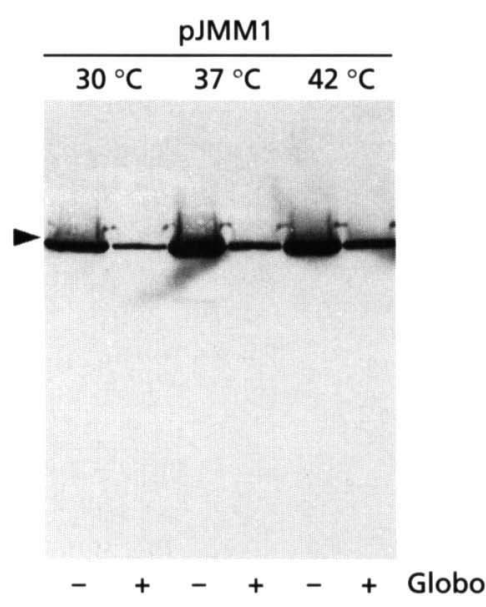

\begin{abstract}
Fig. 1. Effect of globomycin on the synthesis of colicin $A$ at various temperatures. W3110 cells carrying pColA9, pColA9F1, pJMM1, pA2, pV1 or pS18 were induced with mitomycin $C$ and incubated at the temperatures indicated. They were treated with globomycin (Globo) $(t)$ or left untreated $(-)$. After induction, samples were analysed by SDS-PAGE (a). The relevant parts of the gels stained with Coomassie blue are presented. The position of the colicin $A$ is indicated by an arrowhead. Numbers on the right indicate the molecular masses in $\mathrm{kDa}$ of the standard proteins. (b) The blots were probed with the anti-colicin A monoclonal antibody 1C11 (only the reactive portion of the blots is shown).
\end{abstract}

were detected, indicating that proteolysis did not occur, particularly as the C-terminal part of colicin A is highly resistant to proteases (Martinez et al., 1983) and would accumulate after proteolytic degradation.

\section{Effect of heat shock and azide treatment on the synthesis of colicin $A$ in the presence of globomycin}

The delay in the synthesis of colicin A observed at $30^{\circ} \mathrm{C}$ in the absence of globomycin is suppressed by either heat shock or treatment with azide or EDTA (Cavard, 1995). The effects of these treatments were therefore tested in the presence of globomycin (Fig. 2a). EDTA did not modify the production of colicin $\mathrm{A}$ in the presence of globomycin, at any temperature. In contrast, a heat shock of $10 \mathrm{~min}$ at $42{ }^{\circ} \mathrm{C}$ restored the production of colicin $\mathrm{A}$ in the presence of globomycin by induced W3110(pColA9) cells incubated at $30^{\circ} \mathrm{C}$. Large amounts of colicin A were produced in the presence of globomycin when the heat shock was at the start of induction, and smaller amounts the later during induction the heat shock was carried out. No such effect was obtained in an $r p o H$ mutant deficient in $\sigma^{32}$, the sigma factor of the RNA polymerase that transcribes two-thirds of the heat-shock genes. No change of colicin A production was observed after a heat shock of 10 or $20 \mathrm{~min}$ in W3110(pJMM1) cells. Thus both the cal gene product and one or more heat-shock protein(s) were required for the production of colicin $\mathrm{A}$ in the presence of globomycin. 

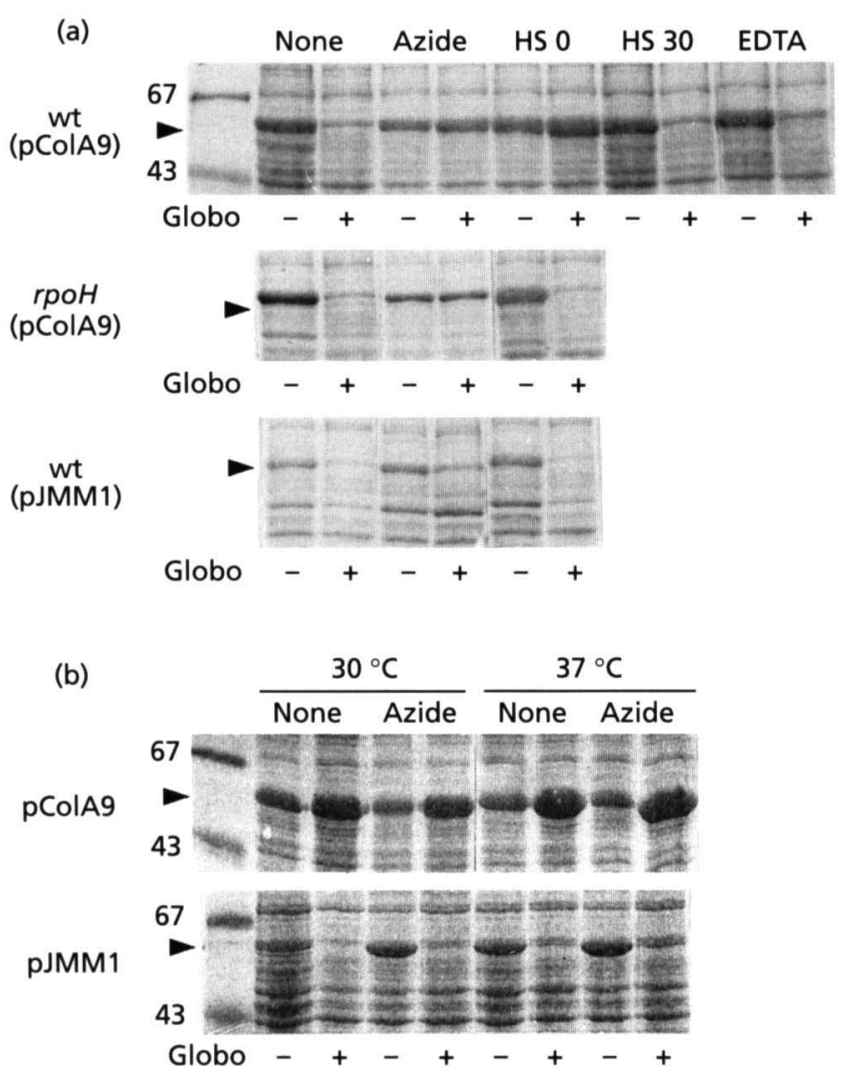

Fig. 2. Synthesis of colicin $A$ in the presence of globomycin after heat shock and azide treatment. (a) Experiment with cells grown in LB. W3110 (wild-type, wt) cells carrying either pColA9 or pJMM1, and $1320 \mathrm{rpoH}$ cells carrying pColA9 were induced and incubated at $30^{\circ} \mathrm{C}$ with no addition (none) or with azide ( $3 \mathrm{mM})$, or after a heat shock at either time zero of induction (HS 0$)$ or $30 \mathrm{~min}$ after induction (HS 30), or with EDTA. They were then treated with globomycin $(+)$ or left untreated $(-)$. At the end of induction, samples were analysed by SDS-PAGE. (b) The same experiment for W3110 in M9 medium. The relevant parts of the gels stained with Coomassie blue are presented. The position of the colicin A is indicated by an arrowhead. Numbers on the left indicate the molecular masses in $\mathrm{KDa}$ of the standard proteins.

Sodium azide also restored the synthesis of colicin $\mathrm{A}$ by W3110(pColA9) cells at $30^{\circ} \mathrm{C}$ in the presence of globomycin to an amount similar to that observed in the absence of globomycin. It did not restore the synthesis of colicin A by induced W3110(pJMM1) cells treated with globomycin, except at $42{ }^{\circ} \mathrm{C}$, at which temperature it provoked a slight increase in the amount of colicin A produced (not shown). As azide is an energy poison, the amount of colicin A produced was smaller in azidetreated than in untreated cells. Another energy poison, potassium cyanide, had the same effects as azide (not shown).

The production of colicin A by induced cells grown in minimal medium was studied (Fig. 2b). W3110(pColA9) produced colicin $\mathrm{A}$ at 30,37 and $42^{\circ} \mathrm{C}$ and there was no evidence of a delay in synthesis at $30^{\circ} \mathrm{C}$. The amount of colicin A was higher in globomycin-treated than in untreated cells. However, W3110(pJMM1) did not produce colicin A in the presence of globomycin at any of the three temperatures, except small amounts at high temperature. Thus growth in minimal medium and treament with energy poisons had similar effects.

\section{Effect of globomycin on the rate of colicin A synthesis}

The effect of globomycin might have been due to a delay in colicin A synthesis after induction. Colicin A production was therefore followed throughout the induction by SDS-PAGE. In W3110(pColA9), colicin A was detected immediately after induction and gradually accumulated with time at $37^{\circ} \mathrm{C}$ (Fig. 3 ) and $42^{\circ} \mathrm{C}$ (not shown), in both the presence and absence of globomycin. At $30^{\circ} \mathrm{C}$, in the absence of globomycin, colicin A was detected from the onset of induction: the amount remained unchanged for $2 \mathrm{~h}$ and increased thereafter. This late increase did not occur in the presence of globomycin. In W3110(pJMM1), the amount of colicin A increased regularly with time of induction at $37^{\circ} \mathrm{C}$ in the absence of globomycin. This increase was delayed at $30^{\circ} \mathrm{C}$. In the presence of globomycin, no colicin A was detected at any temperature.

The rate of colicin A production was analysed in induced cells either treated with azide or subjected to heat shock. The amount of colicin A in W3110(pColA9) cultures increased with time in the presence or absence of globomycin. In W3110(pJMM1), it increased in the absence but not in the presence of globomycin, regardless of temperature (Fig. 3).

The rate of colicin A production in cells grown in minimal medium was determined by pulse-chase labelling. The cells were labelled for $1 \mathrm{~min}$ with $\left[{ }^{35} \mathrm{~S}\right] \mathrm{meth}$ ionine/cysteine mix and chased with non-radioactive amino acids. At various times after the chase, colicin A was immunoprecipitated with a specific antiserum (Fig. 4). Colicin A was detected from the first minute of the chase and its concentration was stable throughout: it was significantly higher in W3110(pColA9) than in W3110(pJMM1). For W3110(pColA9), it was similar in the presence and absence of globomycin, whereas in W3110(pJMM1) cultures it was significantly lower in the presence than in the absence of globomycin.

\section{Effect of globomycin on the synthesis of the cal gene product}

As globomycin blocked the synthesis of colicin A at $30^{\circ} \mathrm{C}$ in cells carrying pColA9, it should also block that of Cal. Cal synthesis in the experiments described above was analysed by immunoblotting, as Cal cannot be visualized by Coomassie blue staining. The antiserum used reveals three forms of $\mathrm{Cal}$ : the precursor form $\mathrm{pCal}$, the modified precursor form $\mathrm{pCal}^{\mathrm{m}}$, and the mature form Cal. In the presence of globomycin, $\mathrm{pCal}^{\mathrm{m}}$ is cleaved at two sites near its C-terminal end by the DegP/HtrA protease, giving two shortened forms of $\mathrm{pCal}^{\mathrm{m}}$ which accumulate (Cavard et al., 1989). As they are not recognized by the polyclonal antibodies used, the 

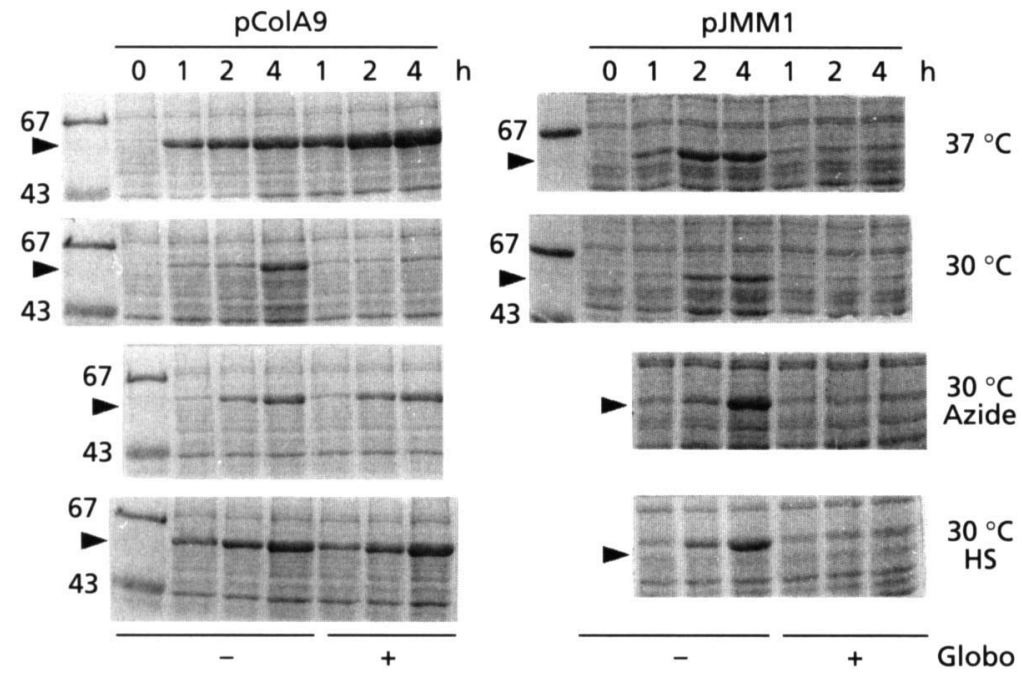

Fig. 3. Rate of synthesis of colicin $A$ in the presence of globomycin. W3110 cells carrying either pColA9 or pJMM1 were induced and incubated at either $37^{\circ} \mathrm{C}$ or $30^{\circ} \mathrm{C}$, with or without azide $(3 \mathrm{mM})$, or after heat shock at time zero of induction (HS) as indicated. They were then treated with globomycin $(+)$ or left untreated $(-)$. At various times of induction as indicated in $h$, samples were taken and analysed by SDSPAGE. The relevant parts of the gels stained with Coomassie blue are presented. The position of the colicin $A$ is indicated by an arrowhead. Numbers on the left indicate the molecular masses in $\mathrm{kDa}$ of the standard proteins.

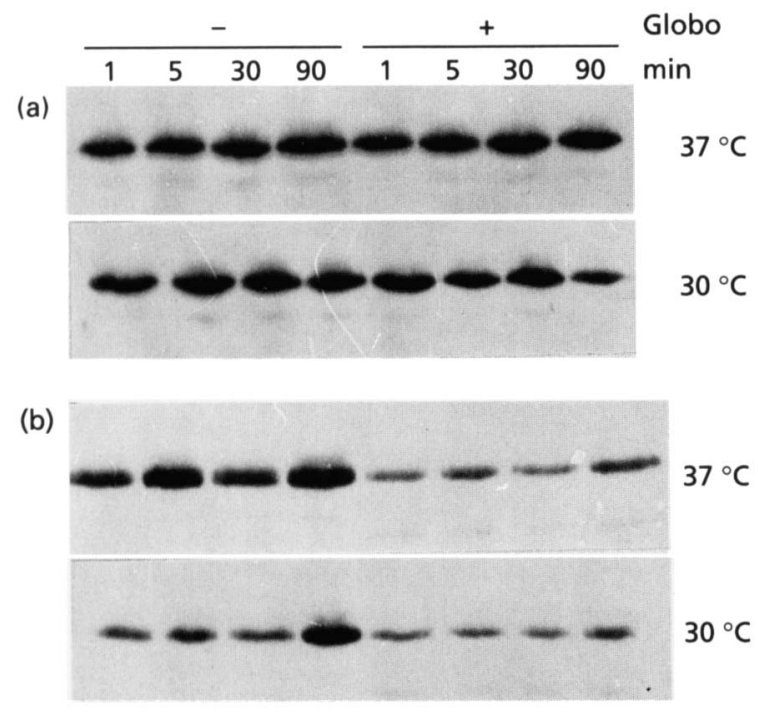

Fig. 4. Stability of the colicin A synthesized in the presence of globomycin. W3110 cells carrying either pColA9 (a) or pJMM1 (b) were grown at $30^{\circ} \mathrm{C}$ in $\mathrm{M} 9$ medium, induced and incubated at either $37^{\circ} \mathrm{C}$ or $30^{\circ} \mathrm{C}$. They were treated with globomycin (+) or left untreated $(-)$. They were labelled with [35S]Protein Labeling Mix for $1 \mathrm{~min}$ and chased with non-radioactive amino acids. At various times after the chase, as indicated in min, samples were taken, immunoprecipitated with anti-colicin A antibodies and analysed by SDS-PAGE. The volume of the loaded samples of W3110(pJMM1) was three times that of the W3110(pColA9) samples. The relevant parts of the fluorograms are presented.

analysis was carried out on both isogenic wild-type and $\operatorname{degP}$ cells (deficient in the DegP protease) (Fig. 5).

In induced cells of $\mathrm{W} 3110$ (pColA9), the three forms of Cal were detected at each temperature in the absence of globomycin, in lower amounts at low than at high temperature. Cal was the major form. In the presence of globomycin, $\mathrm{pCal}^{\mathrm{m}}$ did not accumulate in W3110 (pColA9), but did in W3110 $\operatorname{degP}$ cells at either 37 or
$42{ }^{\circ} \mathrm{C}$. At $30^{\circ} \mathrm{C}, \mathrm{pCal}^{\mathrm{m}}$ was present in low amount. It was often not detected. Thus both genes of the colicin A operon were expressed weakly at $30^{\circ} \mathrm{C}$ in the presence of globomycin.

In cells treated with sodium azide, the amount of each form of Cal was similar at each temperature in the absence of globomycin. Especially, the level of pCal was identical at every temperature, while it was lower at $30^{\circ} \mathrm{C}$ than at 37 and $42{ }^{\circ} \mathrm{C}$ in the absence of azide as already reported (Cavard, 1995). In the presence of globomycin, $\mathrm{pCal}^{\mathrm{m}}$ was detected in $\operatorname{deg} P$ cells at each temperature. The wild-type cells contained a small amount of $\mathrm{pCal}^{\mathrm{m}}$ at $30^{\circ} \mathrm{C}$. This was not due to inhibition of the DegP protease by azide since $\operatorname{DegP}$ was active in the presence of this agent as evidenced at 37 and $42^{\circ} \mathrm{C}$ by the absence of $\mathrm{pCal}{ }^{\mathrm{m}}$, but rather to a defect at $30^{\circ} \mathrm{C}$ of this enzyme, which is a heat-shock protein (Lipinska et al., 1988; Strauch et al., 1989).

The amounts of the various forms of Cal found at $30^{\circ} \mathrm{C}$ increased after a heat shock of $10 \mathrm{~min}$ at $42^{\circ} \mathrm{C}$. The levels of $\mathrm{pCal}$ and $\mathrm{Cal}$ in cells submitted to a heat shock at zero time of induction in the absence of globomycin were similar to those in cells incubated at $42^{\circ} \mathrm{C}$. In the presence of globomycin, the amount of $\mathrm{pCal}^{\mathrm{m}}$ in $\operatorname{deg} P$ cells after a heat shock was similar to that at $42^{\circ} \mathrm{C}$. Less of each of the Cal intermediates was detected when the heat shock was performed $30 \mathrm{~min}$ after induction (not shown). Thus, the relative proportions of the cal gene product and colicin A were constant, confirming that they are co-expressed.

\section{The cal gene product does not modify the sensitivity to globomycin}

Some of the above experiments might suggest that the cal gene product protected cells against killing by globomycin. Globomycin provokes the accumulation of the acylated prolipoproteins by inhibiting their processing into apolipoproteins and signal sequences. This accumulation is toxic, as some minor lipoproteins are 

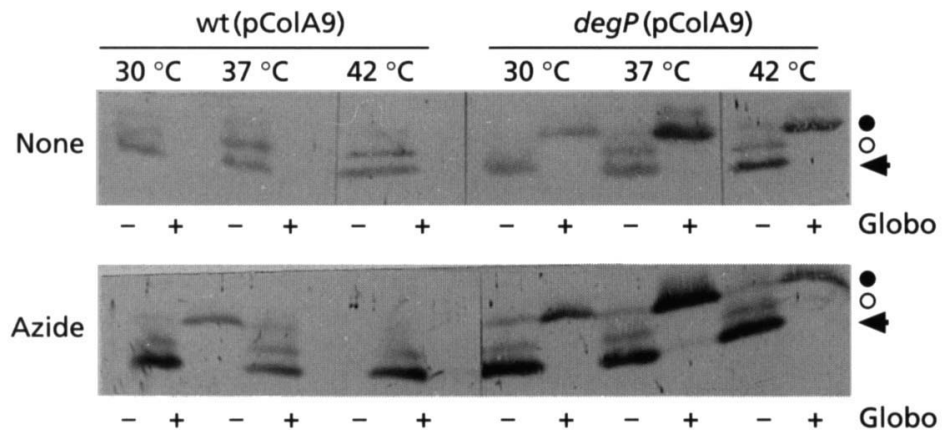

Fig. 5. Effect of globomycin on the synthesis of $\mathrm{Cal}$ in various growth conditions. W3110 (wild-type, wt) and W3110 degP cells carrying pColA9 were induced and incubated at various temperatures as indicated without (none) or with azide $(3 \mathrm{mM})$, or after a heat shock at time zero of induction (HS), before being treated with globomycin $(+)$ or left untreated (-). At the end of induction, samples were analysed by ureaSDS-PAGE. The Western blot of the bottom of the gel is presented. The various forms of Cal are indicated: 0 , precursor form; 0 , modified precursor form; 4 , mature form.

essential for the viability of the cells (Gan et al., 1993). Early killing of the cells would prevent colicin induction from proceeding. Therefore the sensitivity to globomycin of induced and control cells devoid or not of the cal gene was determined as a function of time at various temperatures by measuring the colony-forming ability. The percentage survival was determined from the ratio of colony-forming units of globomycin-treated to untreated samples at a given time. It decreased with time and was influenced by temperature, as killing was obtained faster at $42{ }^{\circ} \mathrm{C}$ than at $30^{\circ} \mathrm{C}$ (Fig. 6a). It was unchanged by induction with mitomycin $\mathrm{C}$ in either W3110 or W3110(pJMM1) cells (not shown).

The $c a l$ gene product is lethal for the producing cells and, consequently, the colony-forming ability decreases rapidly after induction of W3110(pColA9) with mitomycin C (Cavard et al., 1989). It did not protect cells against globomycin. Survival of induced W3110 (pColA9) cells treated by globomycin was slightly weaker than that of untreated ones (not shown).

Survival of globomycin treatment was measured in cells treated with azide or submitted to heat shock (Fig. 6a). Both azide treatment and heat shock significantly reduced globomycin killing of induced and control W3110 cells carrying either no plasmid or pJMM1. Azide protected the cells against globomycin killing more efficiently at low than at high temperature.

The optical density of cultures treated at $37^{\circ} \mathrm{C}$ with globomycin decreases slowly with time (Hussain et al., 1980). Globomycin seemed to make the cells leaky, as various cellular proteins were found in the spent medium of treated cells, as checked by analysis of the pellets and the supernatants of centrifuged cells on SDS-PAGE (Fig. $6 \mathrm{~b})$. This leakiness decreased when the temperature increased: more proteins were found in the supernatants of cells incubated at $30^{\circ} \mathrm{C}$ than in those incubated at $37^{\circ} \mathrm{C}$, and very few at $42^{\circ} \mathrm{C}$. It was similar in uninduced and induced cells carrying either no plasmid or pColA9 or pJMM1. Colicin A, which is a cytoplasmic protein, did not leak from induced cells, suggesting that only the periplasmic proteins were leaking. Treatment with azide significantly decreased the rate of the leakiness provoked by globomycin, but heat shock did not (not shown). This effect of azide on the leakiness provoked by globomycin was obtained on both control and induced cells of W3110 carrying either pColA9 or pJMM1. It cannot thus explain the difference in colicin A synthesis observed in these cells in the presence of globomycin.

Traces of colicin A released by induced cells carrying pJMM1 and pColA9F1 might be sufficient to kill the cells and prevent colicin A induction from proceeding, as neither plasmid contains the immunity gene whose product protects the cell from external colicin A (Geli et al., 1986). However, they grew as well as uninduced cells during the first hours of induction as assessed both by optical density measurements and by colony-forming ability, indicating that there was no killing. Furthermore, the production of colicin A was unchanged when the induction was carried out in the presence of either trypsin, which destroys colicin free in the medium, or vitamin $B_{12}$, which protects the cells against colicin $A$ killing by blocking its receptor BtuB (James et al., 1996) (not shown). Thus, in the absence of a cal gene, colicin A was never released, whatever the presence of globomycin.

\section{DISCUSSION}

This work demonstrates that the cal gene product plays a positive role in the synthesis of colicin A by $E$. coli producing cells. This role was clearly evidenced by treatment with the antibiotic globomycin during induction of the colicin A operon. In the presence of globomycin, colicin A was synthesized in cells carrying the wild-type operon, except at low temperature. At $30^{\circ} \mathrm{C}$, it was synthesized in small amounts in the presence of globomycin and in large amounts in its 
(a)

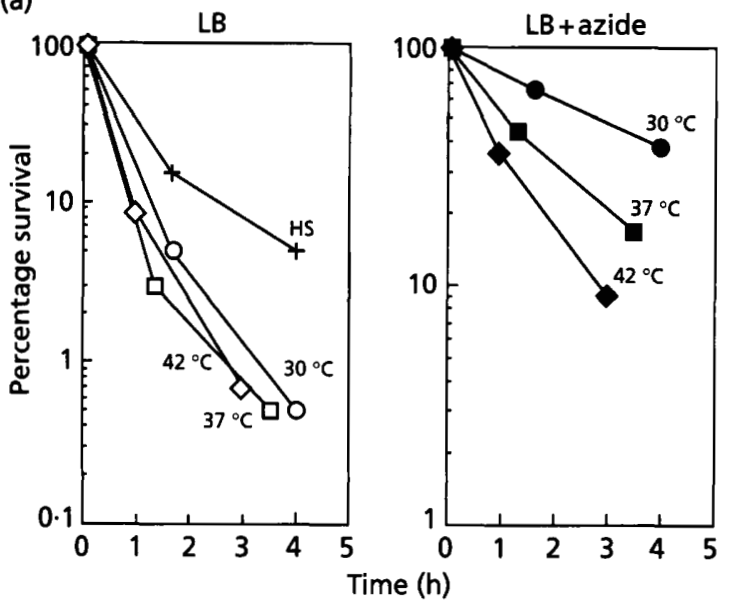

(b)

(b) $30^{\circ} \mathrm{C} \quad 37^{\circ} \mathrm{C} \quad 42^{\circ} \mathrm{C} \quad 30^{\circ} \mathrm{C} \quad 37^{\circ} \mathrm{C} \quad 42^{\circ} \mathrm{C}$

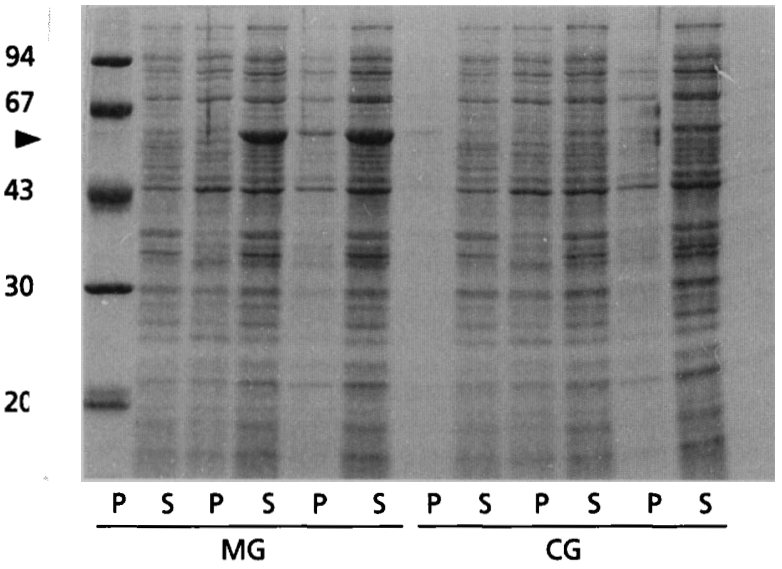

94

67

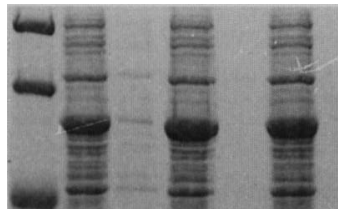

43

30

20

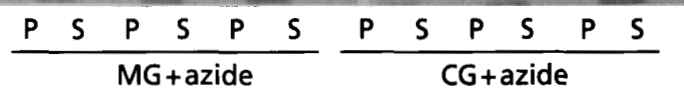

Fig. 6. Effects of globomycin on the survival and on the leakiness of the cells at various temperatures. (a) W3110 cells were treated with globomycin at various temperatures, without azide (LB) or with $2 \mathrm{mM}$ sodium azide (LB + azide) or after being submitted to a heat shock (HS). At various times of incubation, samples were diluted in LB and plated on LB agar. Percentage survival was determined from the ratio of the number of colonies from globomycin-treated samples to the number from untreated samples taken at a given time. (b) W3110(pColA9) cells were treated with globomycin after being induced with mitomycin $C$ (MG) or uninduced (CG) and incubated at various temperatures as indicated, without (top) or with sodium azide $2 \mathrm{mM}$ (bottom). At the end of induction, absence. In cells devoid of the cal gene, only traces of colicin A were synthesized in the presence of globomycin whatever the temperature. Thus a novel phenotype of null cal gene mutants of $E$. coli is described, revealed by treatment with globomycin.

In the absence of globomycin, the amount of colicin A produced was lower in cells with the cal gene deleted than in wild-type cells. This may be due to a positive regulation of colicin A synthesis by the cal gene. Such a regulation by a colicin lysis gene has been previously proposed by Lawrence \& James (1984), who showed that insertion of transposons into the lys gene encoding the colicin E8 lysis protein reduces the production of colicin E8. However, the expression of the colicin A operon provokes a shut-off of chromosomal protein expression (Cavard et al., 1989). Such a shut-off is observed after induction of every operon of the group A colicins which contains a lysis gene, but not after induction of operons of the group B colicins, which are naturally devoid of a lysis gene (reviewed by Pugsley, 1984; van der Wal et al., 1995). The shut-off seems therefore to be due to the expression of the colicin lysis gene. It must favour colicin expression, as the entire cell machinery of transcription and translation may be devoted to it. Thus the reduced synthesis of colicin A observed in cells devoid of the cal gene is presumably caused by the absence of the turn-off of chromosomal protein expression provoked by Cal.

In the presence of globomycin, the cal gene seems to play a positive role in colicin A expression. The precursor forms of the cal gene product might be particularly required for the regulation of colicin A synthesis. Analysis of some cal mutants indicated that the $\mathrm{N}$ terminal part of the cal gene product, that is the signal sequence, was involved in that regulation. The modified precursor form of Cal, $\mathrm{pCal}^{\mathrm{m}}$, like the acylated precursor form of every lipoprotein (Inukai et al., 1978), accumulates in the inner membrane in the presence of globomycin. It is then cleaved by DegP, a periplasmic protease. $\mathrm{pCal}^{\mathrm{m}}$ and its fragments are presumably on the periplasmic face of the cytoplasmic membrane and thus unlikely to be involved in the expression of the colicin A operon. The involvement of the unmodified precursor form of $\mathrm{Cal}, \mathrm{pCal}$, formed in the presence and absence of globomycin, is more likely.

The synthesis of colicin A seemed to start immediately after induction in both the presence and absence of globomycin. At $30^{\circ} \mathrm{C}$, in cells carrying the wild-type colicin A operon, the amount of colicin A was low during the first few hours and only increased thereafter in the absence of globomycin. Thus, at this temperature,

samples were centrifuged, and pellets $(P)$ and supernatants $(S)$ were analysed on SDS-gels. The gels stained with Coomassie blue are presented. The position of the colicin $A$ is indicated by an arrowhead. Numbers on the left indicate the molecular masses in KDa of the standard proteins. 
synthesis was either arrested or slowed rather than delayed as suggested previously (Cavard, 1995). After a lag, the synthesis either started again or speeded up. This lag would be so long that killing would have occurred in cells treated with globomycin, preventing colicin synthesis. At 37 and $42^{\circ} \mathrm{C}$, the lag would be either null or so short in wild-type cells that a large amount of colicin A could be synthesized before killing by globomycin. In contrast, the lag would not end in cells devoid of a cal gene. The signal needed to speed up synthesis would thus involve the cal gene product together with a gene product appearing at normal and high temperature.

Some unrelated agents suppressed the arrest or the slowdown of colicin A synthesis at $30^{\circ} \mathrm{C}$ in cells carrying the cal gene, in both the presence and absence of globomycin. They did not have similar effects on cells devoid of the cal gene, indicating that they act either on or through the cal gene product. All of them - azide, heat shock and growth in synthetic medium - slowed down the rate of cell growth and reduced the sensitivity of the cells to globomycin. Azide is an inhibitor of the SecA translocase and, consequently, of membrane insertion (Oliver et al., 1990). It may favour the insertion of pCal into the membrane, which does not require SecA (Cavard, 1992). On the other hand, azide may speed up the timing of the colicin lysis proteins as it does on the 'lysis clock' of the phage lysis proteins (Young, 1992; Bläsi \& Young, 1996). The Rz lysis gene of bacteriophage $\lambda$ has been recently shown to encode a small lipoprotein (Kedzierska et al., 1996) similar to colicin lysis proteins. Thus the unknown mode of action of azide on phage and colicin lysis proteins might be exerted on lipoproteins. Heat shock provoked the same effect as azide, except in an $r p o H$ strain, suggesting that one or more proteins regulated by $\sigma^{32}$ was/were required for colicin A synthesis. There was a weak production of colicin $\mathrm{A}$ in the presence of globomycin at $42^{\circ} \mathrm{C}$ by cells with no cal gene, indicating that one or more heat-shock protein(s) may complement the cal gene product.

$\mathrm{Cal}$, the colicin A lysis protein, thus appears to exert a positive effect on its own synthesis as it is co-expressed with colicin A. Various phage lysis proteins are regulated at the transcriptional level by complex mechanisms involving themselves (Young, 1992). The self-regulatory role of the cal gene product may be common to all colicin lysis proteins, as their genes are similarly localized in the various colicin operons and their structures are highly homologous (van der Wal et al., 1995). Recently, an activator required for SOS induction of a colicin-like bacteriocin has been described. It is regulated by the SOS response and its sequence is similar to those of phage lysis proteins (Ferrer et al., 1996).

\section{ACKNOWLEDGEMENTS}

I am grateful to Dr Masatoshi Inukai of Sankyo Company (Tokyo, Japan) for the gift of globomycin and to Dr Vincent Geli for the gift of plasmid pColA9F1. I thank Dr Athel Cornish-Bowden for critical reading of the manuscript. This work was supported by the Centre National de la Recherche Scientifique.

\section{REFERENCES}

Blăsi, U. \& Young, R. (1996). Two beginnings for a single purpose: the dual-start holins in the regulation of phage lysis. Mol Microbiol 21, 675-682.

Braun, V. \& Wu, H. C. (1994). Lipoproteins: structure, function, biosynthesis and model for protein export. In Bacterial Cell Wall, pp. 319-341. Edited by J. M. Ghuysen \& R. Hakenbeck. Amsterdam: Elsevier Science.

Cavard, D. (1992). Colicin A and colicin E1 lysis proteins differ in their dependence on $\sec A$ and $\sec Y$ gene products. FEBS Lett 298, 84-88.

Cavard, D. (1995). Effects of temperature and of heat shock on the expression and action of the colicin A lysis protein. J Bacteriol 177, 5189-5192.

Cavard, D., Lazdunski, C. \& Howard, S. P. (1989). The acylated precursor form of the colicin A lysis protein is a natural substrate of the DegP protease. J Bacteriol 171, 6316-6322.

Eraso, J. M. \& Weinstock, G. M. (1992). Anaerobic control of colicin E1 production. J Bacteriol 174, 5101-5109.

Eraso, J. M., Chidambaram, M. \& Weinstock, G. M. (1996). Increased production of colicin E1 in stationary phase. J Bacteriol 178, 1928-1935.

Ferrer, S., Viejo, M. B., Guasch, J. F., Enfedaque, J. \& Regué, M. (1996). Genetic evidence for an activator required for induction of colicin-like bacteriocin $28 \mathrm{~b}$ production in Serratia marcescens by DNA-damaging agents. J Bacteriol 178, 951-960.

Gan, K., Gupta, S. D., Sankaran, K., Schmid, M. B. \& Wu, H. C. (1993). Isolation and characterization of a temperature-sensitive mutant of Salmonella typhimurium defective in prolipoprotein modification. J Biol Chem 268, 16544-16550.

Geli, V., Baty, D., Crozel, V., Morlon, J., Lloubès, R., Pattus, F. \& Lazdunski, C. (1986). A molecular genetic approach to the functioning of the immunity protein to colicin A. Mol Gen Genet 202, 455-460.

Howard, S. P. \& Lindsay, L. (1992). Structure/function relationships in the signal sequence of the colicin A lysis protein. In Bacteriocins, Microcins and Lantibiotics (NATO ASI series H65), pp. 317-329. Edited by R. James, C. Lazdunski \& F. Pattus. Berlin: Springer.

Howard, S. P., Cavard, D. \& Lazdunski, C. (1989). Amino acid sequence and length requirements for assembly and function of the colicin A lysis protein. J Bacteriol 171, 410-418.

Hussain, M., Ichihara, S. \& Mizushima, S. (1980). Accumulation of glyceride-containing precursor of the outer membrane lipoprotein in the cytoplasmic membrane of Escherichia coli treated with globomycin. J Biol Chem 255, 3707-3712.

Inukai, M., Takeuchi, M., Shimizu, K. \& Arai, M. (1978). Mechanism of action of globomycin. J Antibiot 31, 1203-1205.

James, R., Kleanthous, C. \& Moore, G. R. (1996). The biology of E colicins: paradigms and paradoxes. Microbiology 142, 15691580.

Kedzierska, S., Wawrzynow, A. \& Taylor, A. (1996). The Rz1 gene product of bacteriophage $\lambda$ is a lipoprotein localized in the outer membrane of Escherichia coli. Gene 168, 1-8.

Lawrence, G. M. P. \& James, R. (1984). Characterization of the ColE8 plasmid, a new member of the group E colicin plasmids. Gene 29, 145-155.

Lipinska, B., Sharma, S. \& Georgopoulos, C. (1988). Sequence 
analysis and regulation of the htrA gene of Escherichia coli: a $\sigma^{32}$ independent mechanism of heat-inducible transcription. Nucleic Acids Res 16, 10053-10067.

Lloubès, R., Baty, D. \& Lazdunski, C. (1986). The promoters of the genes for colicin production, release and immunity in the ColA plasmid: effects of convergent transcription and LexA protein. Nucleic Acids Res 14, 2621-2636.

Martinez, M. C., Lazdunski, C. \& Pattus, F. (1983). Isolation, molecular and functional properties of the $\mathrm{C}$-terminal domain of colicin A. EMBO J 2, 1501-1507.

Oliver, D. B., Cabelli, R. J., Dolan, K. M. \& Jarosik, G. P. (1990). Azide-resistant mutants of Escherichia coli alter the SecA protein, an azide-sensitive component of the protein export machinery. Proc Natl Acad Sci USA 87, 8277-8231.

Pugsley, A. P. (1984). The ins and outs of colicins. Part $I$. Production and translocation across membranes. Microbiol Sci $\mathbf{1}$, 168-175.
Strauch, K. L., Johnson, K. \& Beckwith, J. (1989). Characterization of $\operatorname{deg} P$, a gene required for proteolysis in the cell envelope and essential for growth of Escherichia coli at high temperature. J Bacteriol 171, 2689-2696.

Tian, G., Wu, H. C., Ray, P. H. \& Tai, P. C. (1989). Temperaturedependent insertion of prolipoprotein into Escherichia coli membrane vesicles and requirements for ATP, soluble factors, and functional SecY protein for the overall translocation process. J Bacteriol 171, 1987-1997.

van der Wal, F., Luirink, J. \& Oudega, B. (1995). Bacteriocin release proteins: mode of action, structure, and biotechnological application. FEMS Microbiol Rev 17, 381-399.

Young, R. (1992). Bacteriophage lysis: mechanism and regulation. Microb Rev 56, 430-481.

Received 14 January 1997; revised 3 March 1997; accepted 7 March 1997. 